\title{
Influence of Nordic Walking training on static and dynamic body balance among the elderly
}

\author{
Zbigniew Ossowski ${ }^{1}$ ABDEF, Marek Wawryniuk ${ }^{2 C D}$ \\ Vida Janina Česnaitiené ${ }^{3 \mathrm{AF}}$
}

Authors' Contribution:

A Study Design

B Data Collection

C Statistical Analysis

D Data Interpretation

E Manuscript Preparation

F Literature Search

G Funds Collection

\section{abstract}

Background

Material/Methods

Results

Conclusions

Key words

\author{
${ }^{1}$ Gdansk University of Physical Education and Sport in Gdansk, Poland \\ 2 Medical University of Gdansk, Poland \\ ${ }^{3}$ Lithuanian Sports University, Lithuania
}

\section{article details}

Article statistics

Full-text PDF:

Copyright

Indexation:

Funding:

Competing interests: Corresponding author:

Open Access License:

Regression of body balance function is one of the main risk factors in falls among the elderly. The aim of this article was to evaluate changes in static and dynamic body balance levels among people over 65 years under the influence of Nordic Walking training.

The research was conducted with participation of 21 people over 65 years old. The training lasted throughout a period of 6 months. Frequency of exercises was twice a week. Evaluation was conducted using 8-Foot Up-and-Go from the Senior Fitness Test and a single leg balance test from the EUROFIT test for adults.

A general tendency for body balance improvement was observed among the elderly under the influence of Nordic Walking training. The average test results for static body balance level were improved by $4.32 \%$. In the case of dynamic body balance the increase was $5.68 \%$.

Loss of body balance is a problem affecting almost $14 \%$ of the population between $50-60$ years of age. In the subsequent decade of life the risk of a fall increases to $22 \%$ on average, and among octogenarians the problem concerns over $33 \%$ of them. The research described below shows that using Nordic Walking training is advisable as a preventive measure against further diminishing of dynamic and static body balance among the elderly.

Nordic Walking, body balance, the elderly.

Word count: 2080; Tables: 3; Figures: 4; References: 31

Received: January 2014; Accepted: November 2014; Published: March 2015

http://www.balticsportscience.com

๑ Gdansk University of Physical Education and Sport, Poland

Celdes, CNKI Scholar (China National Knowledge Infrastructure), CNPIEC, De Gruyter - IBR (International Bibliography of Reviews of Scholarly Literature in the Humanities and Social Sciences), De Gruyter - IBZ (International Bibliography of Periodical Literature in the Humanities and Social Sciences), DOAJ, EBSCO - Central \& Eastern European Academic Source, EBSCO - SPORTDiscus, EBSCO Discovery Service, Google Scholar, Index Copernicus, J-Gate, Naviga (Softweco, Primo Central (ExLibris), ProQuest - Family Health, ProQuest - Health \& Medical Complete, ProQuest - Illustrata: Health Sciences, ProQuest - Nursing \& Allied Health Source, Summon (Serials Solutions/ProQuest, TDOne (TDNet), Ulrich's Periodicals Directory/ulrichsweb, WorldCat (OCLC)

No external funding was received.

Author has declared that no competing interest exists.

Dr. Zbigniew Ossowski, Gdansk University of Physical Education and Sport, K. Górskiego St. 1, 80-336 Gdansk, Poland

Phone: 4858 554- 71-84, e-mail: awfis.rek@wp.pl

This is an open access article distributed under the terms of the Creative Commons Attribution-Non-commercial 4.0 International (http://creativecommons.org/licenses/by-nc/4.0/), which permits use, distribution, and reproduction in any medium, provided the original work is properly cited, the use is non-commercial and is otherwise in compliance with the license. 


\section{INTRODUCTION}

Demographic forecast spanning forthcoming years suggests that the number of the elderly within a population will rise significantly. According to GUS (Central Statistical Office, Poland), in 2013 the number of people over 60 years old living in Poland was $8,239,170$, which amounts to $21.8 \%$ of the country's population. The proportion of people over 60 predicted for the year 2023 is $27.5 \%$ [1].

Ageing is a natural process resulting in many physiological changes debilitating functions of a human body. A selected number of factors influencing the probability of falls in this age group are: a decrease in physical activity due to weakening of the muscular apparatus, a loss of body balance, dizziness and visual impairment [2, 3].

One of the preventive measures against the loss of body balance could be Nordic Walking training, which is currently quite popular especially among the elderly [4]. Its healthful effects for the vascular, muscular and respiratory systems are widely known. Nordic Walking training is also effective in improving general fitness of the elderly, e.g. their endurance and flexibility [5]. This kind of training is also used for rehabilitation of patients with cardiovascular incidents, obesity, Parkinson's disease, etc. [6, 7, 8].

The subject of body balance regression with age - one of the risk factors of falls - is quite essential and topical. Falls are very dangerous for the elderly because they often cause injuries and bone fractures $[9,10]$. Falls are one of the main causes of disability and the fifth most frequent cause of death among people over 75 years of age [11].

National Health Interview Survey shows that falls are the biggest single cause of limited physical activity among older adults [12]. In consequence, falls also generate huge costs related to hospitalization and treatment $[13,14]$.

Existing literature on the subject provides very little information about the significance of Nordic Walking training (as a rehabilitation practice) for body balance loss among the elderly.

The aim of this study was to determine the degree of influence of Nordic Walking training (NW) on static and dynamic body balance of people over 65 .

\section{MATERIAL AND METHODS}

The test group consisted of 21 women aged over 65 residing in Tricity (Gdańsk - Sopot - Gdynia, Poland). The participants responded to a recruitment invitation advertisement placed on the premises of various churches. All the persons partaking in the study underwent obligatory medical examination to ensure there are no contraindications against recreational physical effort. Participants were informed about the goal of the study and voluntarily consented to take part in it.

The characteristics of selected somatic features in the test group are presented in the table below. 
Table. 1. Characteristics of selected somatic features in the test group

\begin{tabular}{lll} 
& $\mathrm{n}=21$ & \\
\cline { 2 - 3 } Selected somatic features & $\bar{X}$ & SD \\
\hline Age & 69.5 & 4.5 \\
\hline Weight & 66.4 & 9.7 \\
\hline Height & 162.2 & 7.3 \\
\hline BMI & 25.4 & 3.5 \\
\hline
\end{tabular}

The test group participated in Nordic Walking training throughout a period of 6 months, twice a week. The main part of the exercise program was based on march training with poles at a distance of 3-4 kilometers. The intensity of trainings oscillated between $50-70 \%$.

Evaluation was conducted using 8-Foot Up-and-Go from the Senior Fitness Test and a single leg balance test from the EUROFIT test for adults [15, 16].

The collected data was then processed using basic statistical measures with a use of computer software Statistica 10 PL.

\section{RESULTS}

A comparison of the static balance level in the one-leg standing test at the beginning (before training NW) and at the end (after training NW) is presented in the table below (Table 2).

Table. 2. A comparison of the static balance level in the one-leg standing test, before and after training Nordic Walking training

\begin{tabular}{|c|c|c|c|c|c|c|c|c|c|c|c|c|c|}
\hline & \multicolumn{13}{|c|}{ Single leg balance test [number of support] } \\
\hline & befor & NW & & & & after & & & & & difference & & \\
\hline & $X$ & SD & $\min$ & $\max$ & V\% & $X$ & SD & $\min$ & $\max$ & V\% & $\begin{array}{l}\text { number of } \\
\text { supports }\end{array}$ & $\%$ & $\mathrm{t}$ \\
\hline $\begin{array}{l}\underset{\sim}{N} \\
\text { II }\end{array}$ & 8.81 & 5.57 & 1 & 23 & 63.22 & 8.43 & 4.76 & 1 & 15 & 56.47 & -0.38 & 4.32 & 0.39 \\
\hline
\end{tabular}

An analysis of the research material showed that static body balance tends to improve under the influence of Nordic Walking training. The initial average results of the one-leg standing test showed a support factor of 8.81 and the final average results of the test indicated a factor of 8.43. The difference between these two averages is $4.32 \%$. However, the results of the one-leg standing test between the two groups were not improved enough to be statistically relevant.

The average results for the discussed trial together with standard deviations were presented in Fig. 1. 


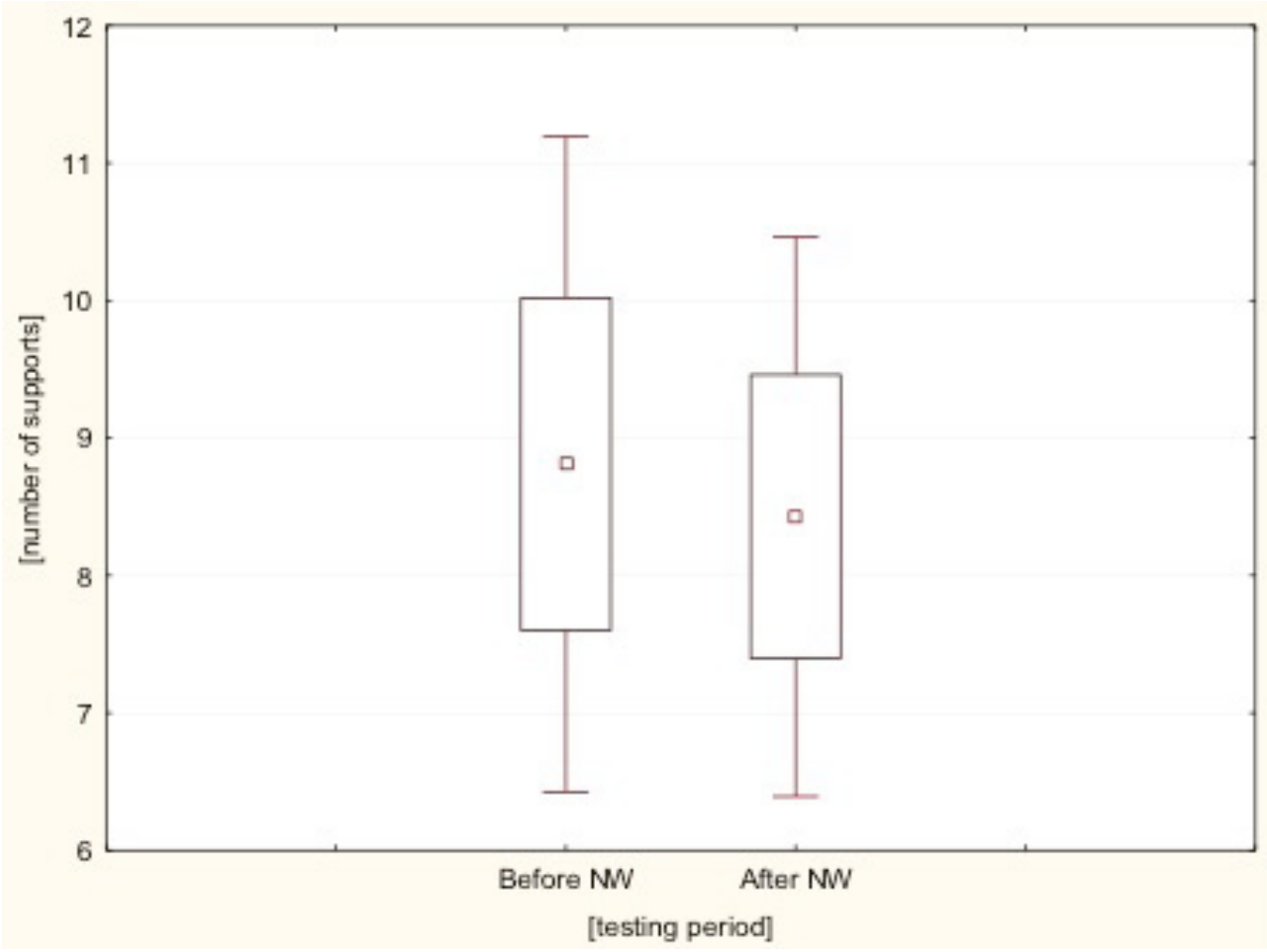

Fig. 1. The average results obtained in a one-leg standing test before and after Nordic Walking training

Further detailed analysis indicated that within the group of 21 tested persons: 10 of them (47.6\%) improved their static body balance, 3 of them $(14.2 \%)$ showed no change and among 8 of them (38.2\%) body balance results decreased. A detailed analysis of the changes in the level of static balance under the influence of Nordic Walking training is presented in Fig. 2.

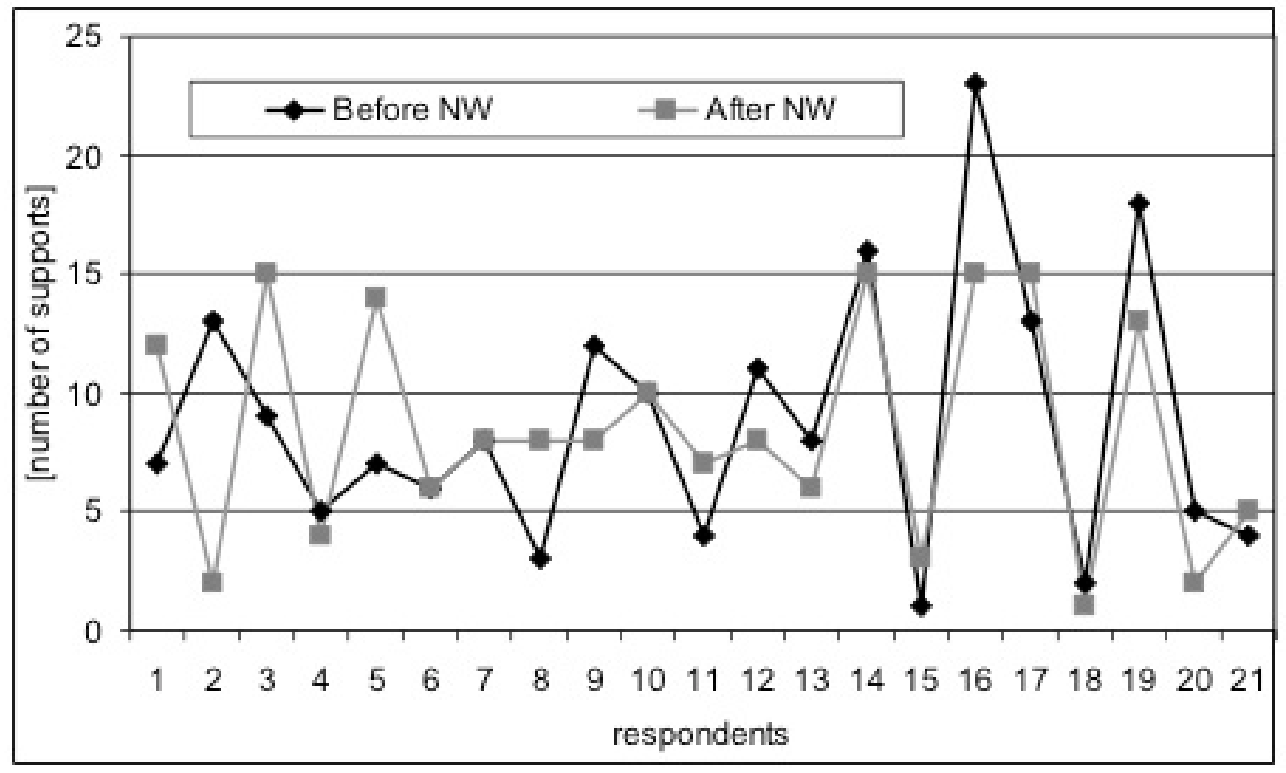

Fig. 2. Individual analysis of changes in the level of static balance in subjects under Nordic Walking training 
The subsequent part of this study presents an analysis of the 8-Foot Up-and-Go from the Senior Fitness Test. The comparison of levels of agility and dynamic balance in subjects is presented in Tab.3.

Table. 3. A comparison of levels of agility and dynamic balance in subjects in the sample 8-Foot Up-and-Go before and after Nordic Walking training

\begin{tabular}{|c|c|c|c|c|c|c|c|c|c|c|c|c|c|}
\hline \multirow[b]{3}{*}{$\underset{\|}{\vec{N}}$} & \multicolumn{13}{|c|}{ 8-Foot Up-and-Go [s] } \\
\hline & Befor & NW & & \multicolumn{6}{|c|}{ After NW } & \multicolumn{4}{|c|}{ Difference } \\
\hline & $\bar{X}$ & SD & $\min$ & $\max$ & V\% & $\bar{X}$ & SD & $\min$ & $\max$ & V\% & $\mathrm{s}$ & $\%$ & $\mathrm{t}$ \\
\hline$\stackrel{11}{\simeq}$ & 4.58 & 0.73 & 3.65 & 7 & 15.9 & 4.32 & 0.6 & 3.52 & 5.94 & 13.9 & -0.26 & 5.68 & 1.9 \\
\hline
\end{tabular}

Results of the second test also indicated a tendency for improvement in agility and dynamic body balance. The average improvement was evaluated at $5.68 \%$. The difference between initial and final results (shown in Table 3) was not statistically relevant.

In contrast to the data obtained through a single leg balance test, here the results dispersion within the analyzed sample was much lower. The variability factor oscillated between 13.9-15.9\%.

The average results and standard deviations obtained in the analyzed sample before and after the training process are presented in Fig.3.

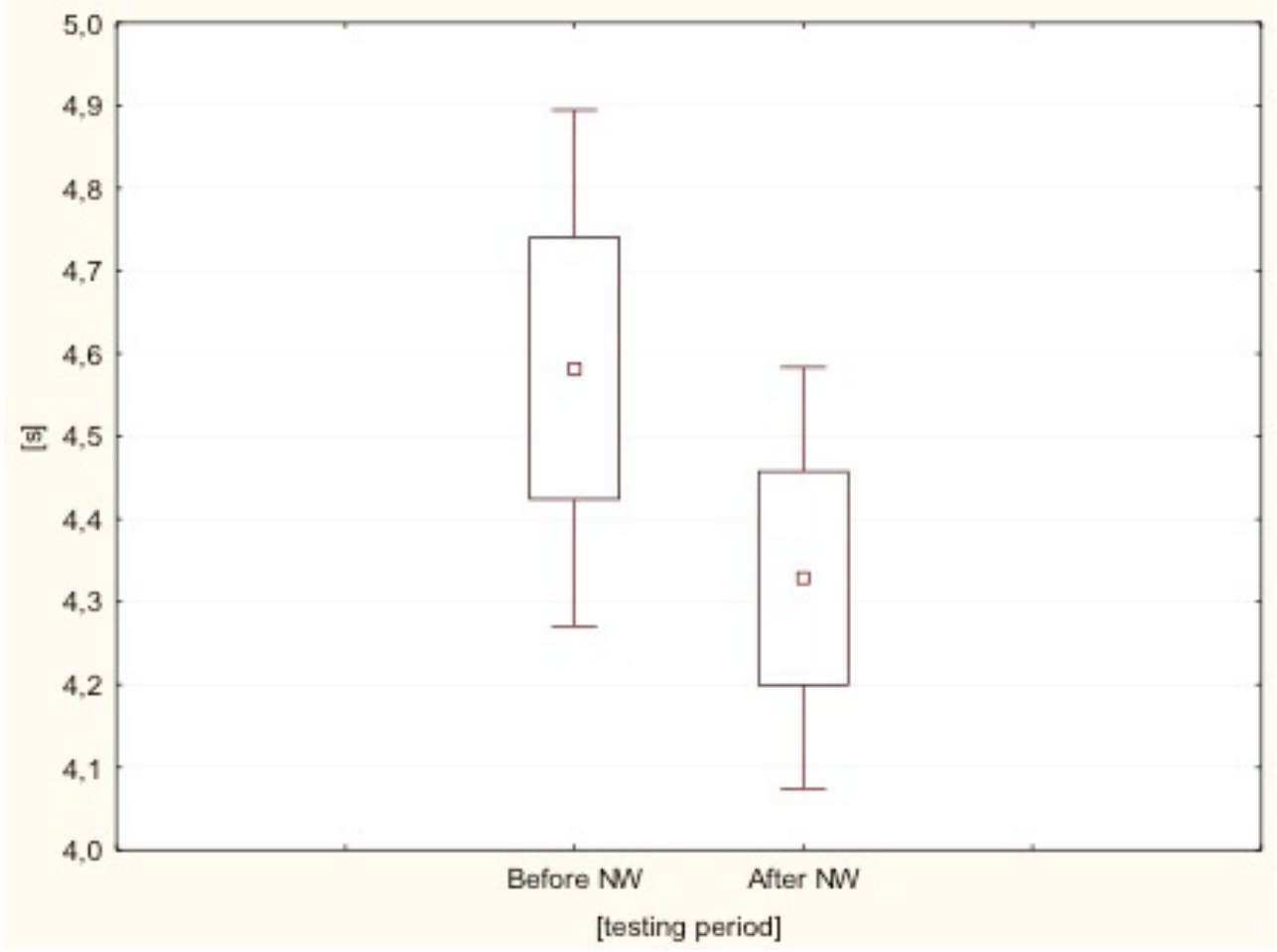

Fig. 3. Average values obtained in sample 8-Foot Up-and-Go before and after Nordic Walking training

The results analysis indicated that 14 persons (66.7\%) showed improvement in their dynamic bodybalance, and 7 ofthem (33.3\%) decreased theirperformance. The changes in the level of agility and dynamic balance under Nordic Walking training are shown in Fig. 4. 


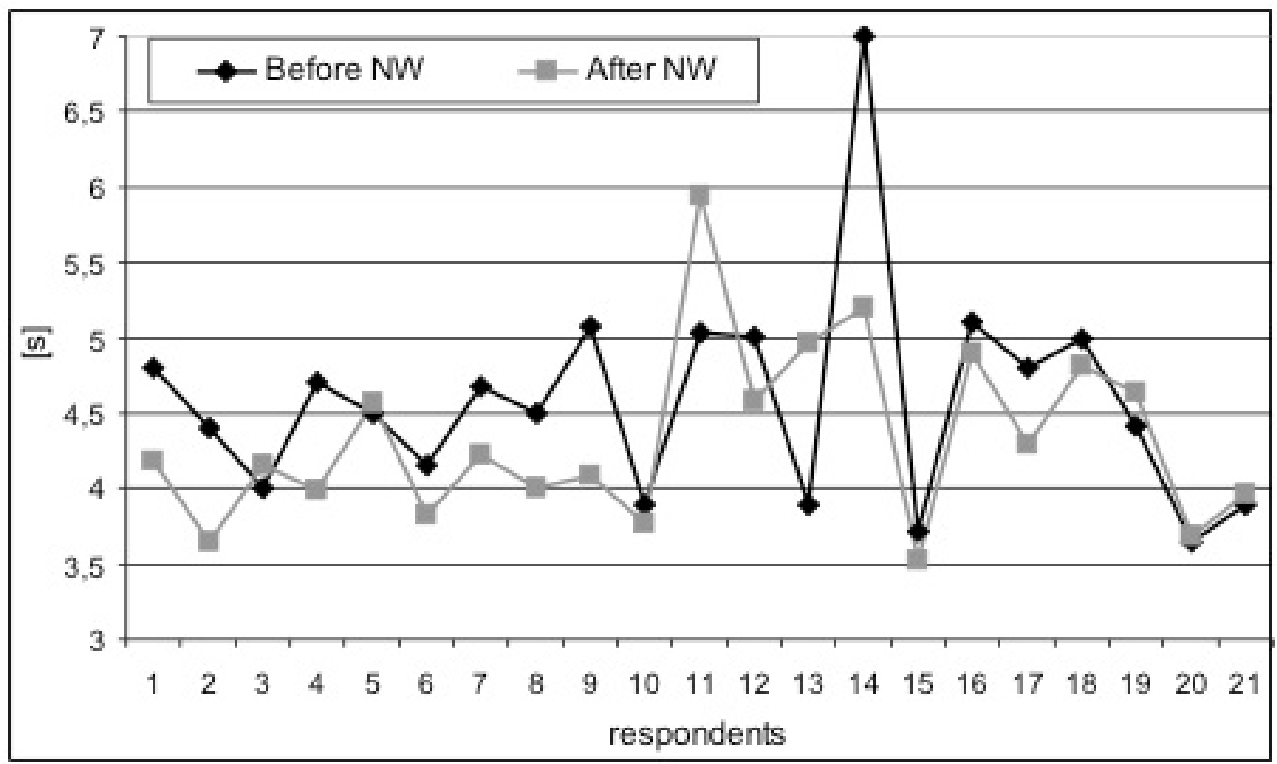

Fig. 4. Individual analysis of changes in the level of agility and dynamic balance in subjects undertaking Nordic Walking training

\section{DISCUSSION}

As part of human locomotor structure, many authors consider body balance to be one of specific coordination skills, i.e. psychomotor properties indicating readiness for optimal control and regulation of motor actions.

A sense of dynamic and static body balance reaches its peak around the age of 18 in women and around the age of 25 in men. A loss of static body balance can be expected over the age of 25 at the earliest, whereas the early threshold for the loss of dynamic body balance is over 35 years of age [17].

To generalize, a gradual degradation of the balance system function can be observed since the third decade of a person's life. Results of this process become evident especially in the old age when insufficiency of the balance system is one of the main causes of falls.

Literature on the subject is replete with examples of many various studies, experiments and opinions on building optimal improvement programs aimed at increasing body balance as prevention against falls. This discussion presents only a selected sample of programs based on physical activity which - in the opinion of the present authors - were well documented in the literature on the subject.

Province et al. researched in their paper the correlation between physical exercises and falls. They claimed that - apart from certain exceptions - exercises were responsible for a significant reduction in falls. The best effects were observed with the use of Tai Chi Chuan and an individual exercise program. Derived from Chinese martial arts, Tai Chi exercises involve slow rhythmic movements which emphasize twists of the body, shifting the center of gravity, motoric coordination and placing lower limbs gradually closer together. Individual exercise program emphasized general fitness including flexibility improvement and body balance training [18]. 
Similar results were achieved by Madureira et al. who researched the effectiveness of 12 months long training aimed at improving levels of body balance and mobility. The experiment was conducted with the participation of 66 women over 65 years old. They trained once a week for one hour in addition to practicing a home exercise program. The study results indicated body balance improvement at statistical significance of $p<0.001$. Long-range research perspective showed that body balance training is effective in improving functional and static body balance as well as mobility and that it also reduces occurrence of falls [19].

Rubenstein, citing numerous meta-analyses, claims that fitness improvement programs should include exercises building up strength, correcting walking stance and developing body balance and endurance [13]. Other researchers present similar views arguing that exercises encompassing training of strength, body balance, walk and coordination should be introduced as intervention means preventing falls among the elderly. It could be applied either as a single intervention or as a compound multifactorial program. Best effects were demonstrated in programs lasting over 12 weeks ( 1 to 3 times a week) with varying intensity $[20,21,22]$.

Despite extensive experience in the field of body balance training aimed at the elderly, scholars are still researching new solutions driving invention of preventive programs to improve body balance and reduce occurrence of falls among the elderly.

The present study indicates that static and dynamic body balance tends to improve among the elderly under the influence of Nordic Walking training (yet the improvement level was not statistically relevant). Statistical irrelevance was caused by instances of regression of body balance observed in certain women ( 8 cases of static balance loss and 7 cases of dynamic balance loss). Further analysis showed that 4 of the cases in each group were in fact the same persons. Scrutiny of selected descriptive indexes characterizing the aforementioned persons and their subsequent comparison with the rest of the group did not display any significant differences in age or height. A slight difference was present in BMI of persons with decreased body balance - which was 2.4 points higher. Our previous research showed higher effectiveness of Nordic Walking training in a group of women aged 60-65 than in a group of older persons - aged 65-69 [23]. Other studies also indicate that age is negatively correlated with strength of lower limbs and positively correlated with a drop in postural balance [24].

Interpreting the results, one should also keep in mind that the function of body balance decreases as result of involution in many systems responsible for maintaining body balance. Wolfson et al. especially point out the sense of sight and reverse changes in proprioceptors [25]. Other authors claim that among the causes of body balance decrease are also: general muscle atrophy (especially loss of strength in lower limbs), changes in the central and the peripheral nervous system (which cause a slower reaction time and slower transmission of nerve impulses) as well as locomotor system diseases [24, 26, 27, 28]. The aforementioned factors can also affect the pace of a possible positive change in body balance under the influence of the recommended physical training. 
Summing up the present experiment, it is advisable - in further research using Nordic Walking training - to expand the training program with balancing exercises performed stationary and in motion. Moreover, it is recommended to personalize balancing exercises intensity taking into account any diseases, among others, of the locomotor and the nervous systems.

Nordic Walking training with its well documented health benefits [29, 30, 31] and increasing popularity, especially among the elderly, justifies deeper research particularly in its potential influ-ence as a preventive measure lowering risk factors of falls among the elderly.

\section{CONCLUSION}

1. Under the influence of Nordic Walking training a tendency for improvement was ob-served among the elderly, resulting in static body balance increased by $4.32 \%$ and dynamic body balance by $5.68 \%$.

2. To heighten the efficiency of Nordic Walking training pertaining to body balance, we suggest expand the training program with balancing exercises stationary and in motion.

3. Appropriate training load should be dependent on participants' health condition with special attention towards diseases of the nervous and the locomotor systems.

\section{REFERENCES}

[1] Struktura ludnosci. Polska 1975-2030 [Structure of the population. Poland 1975-2030]. GUS, http://www. stat.gov.pl/PI_gus/ludnosc_piramida/start.htm, accessed on 10.09.2013. Polish.

[2] Szpringer M, Wybraniec-Lewicka B, Czerwiak G, Michalowska M, Krawczynska J. Upadki i urazy wieku geriatrycznego [Falls and injuries in geriatric age]. Studia Medyczne. 2008;9:77-81. Polish.

[3] Karlsson MK, Vonschewelov T, Karlsson C, Cöster M, Rosengen BE. Prevention of falls in the elderly: A review. Scand J Public Health July 2013; 41:442-454.

[4] Ossowski Z, Kortas J. Wstepne badania nad wplywem rekreacyjnego treningu Nordic Walking na poziom zwinnosci i rownowagi u kobiet w wieku 60-69 lat [Preliminary research on the influence of Nor-dic Walking training on the level of agility and body balance in women aged 60-69 years]. Logistyka. 2012;3:17831789. Polish.

[5] Ossowski Z, Cesnaitiene VJ. Influence of Nordic Walking training on physical endurance in elderly wom-en. In: Current issues and new ideas in sport science: 5th Baltic Sport Science Conference, Kaunas, Lithuania, 18-19 April 2012:154.

[6] Mikalacki M, Cokorilo N, Katic R. Effect of Nordic Walking on functional ability and blood pressure in elderly women. Coll Antropol. 2011;35(3):889-94.

[7] Figard-Fabre H, Fabre N, Leonardi A, Schena F. Efficacy of Nordic walking in obesity management. Int J Sports Med. 2011;32(6):407-14.

[8] Fritz B, Rombach S, Godau J, Berg D, Horstmann T, Grau S. The influence of Nordic Walking training on sit-to-stand transfer in Parkinson patients. Gait Posture. 2011;34(2):234-8.

[9] World Health Organization WHO. A Global Report on Falls Prevention Epidemiology of Falls, 2007.

[10] Przydatek M, Wielkie problemy geriatryczne: Upadki [Falls as serious geriatric problems]. Medycyna Rodzinna. 2001;13/2. Polish

[11] Scuffham P, Chaplin S, Legood R., Incidence and costs of unintentional falls in older people in the United Kingdom. Journal of Epidemiology and Community Health. 2003;57(9):740-744.

[12] Rubenstein LZ. Falls in older people: epidemiology, risk factors and strategies for prevention. Age and Ageing 2006; 35-S2, 37-41.

[13] Stevens JA, Corso PS, Finkelstein EA, Miller TR. The cost of fatal and nonfatal falls among older adults. Inj Prev. 2006;12(5):290-29. 
[14] Scuffham P, Chaplin S, Legood R, Incidence and costs of unintentional falls In older people in the United Kingdom. Journal of Epidemiology and Community Health. 2003;57(9):740-744.

[15] Rikli RE, Jones CJ. Senior Fitness Test Manual. Champaign, Ill.: Human Kinetics; 2001.

[16] Jegier A, Kozdron E. Metody oceny sprawnosci i wydolnosci fizycznej czlowieka [Rating methods for fitness and physical capacity of a human being]. Warszawa: TKKF; 1997. Polish.

[17] Wolański N. Rozwoj biologiczny czlowieka. Podstawy auksologii, gerontologii i promocji zdrowia [Bio-logical development of a human. Basics of auxology, gerontology and health promotion]. Warszawa: PWN; 2005. Polish.

[18] Province MA, Hadley EC, Hornbrook MC, et al. The effects of exercise on falls in elderly patients. A preplanned meta-analysis of the FICSIT trials. JAMA. 1995;273:1341-1347.

[19] Madureira MM, Takayama L, Gallinaro AL, Caparbo VF, Costa RA, Pereira RMR. Balance training program is highly effective in improving functional status and reducing the risk of falls in elderly women with osteoporosis: a randomized controlled trial. Osteoporos Int. 2007;18(4):419-425.

[20] Gillespie LD, Gillespie WJ, Robertson MC, Lamb SE, Cumming RG, Rowe BH. Interventions for preventing falls in elderly people (Cochrane Review). Cochrane Library 2003, Issue 4. Oxford: Updated Software.

[21] Chang JT, Morton SC, Rubenstein LZ, et al. Interventions for the prevention of falls in older adults: Systematic review and meta-analysis of randomized clinical trials. BMJ. 2004;328:680-683.

[22] Gardner MM, Robertson MC, Campbell AJ. Exercise in preventing falls and fall related injuries in older people: A review of randomised controlled trials.Br J Sports Med. 2000;34:7-17.

[23] Ossowski Z, Prusik K, Kortas J, Wiech M, Prusik K, Slomska H, Bielawa L. Zmiany poziomu siły konczyn gornych i dolnych pod wplywem treningu Nordic Walking u kobiet w starszym wieku [Changes in the level of strength of upper and lower limbs under Nordic walking training in elderly women]. Rocznik Naukowy AWFiS Gdansk. 2010;20:71-78. Polish.

[24] Wiacek M, Hagner W, Hagner-Derengowska M, et al. Correlations between postural stability and strength of lower body extremities of women population living in long-term care facilities. Arch Gerontol Geriatr. 2009;48(3):346-349.

[25] Wolfson L, Whipple R, Derby CA, et al. dynamic posturography study oh balance in healthy elderly. Neurology. 1992;42:2069.

[26] Gehlsen G, Mitchell HW. Falls in the frail elderly: part II, balance, strength and flexibility. Arch Phys Med Rehab. 1990;71:739-741.

[27] Fried AV, Cwikel J, Ring H, Galinsky D. EL-GAM-extra-laboratory gait assessment method: identification of risk factor for falls among the elderly at home. Int Disabil Studies. 1990;12(4):161-164.

[28] Zak M. Wplyw fizjoterapii na rownowagę i chod osob w starszym wieku [The influence of physiotherapy on balance and gait in the elderly]. Fizjoterapia. 2005;13/4:17-23. Polish.

[29] Wiech M, Prusik K, Prusik K, Ossowski Z, Kortas J, Slomska H. Zmiany wybranych pozytywnych miernikow zdrowia u seniorow pod wplywem treningu Nordic Walking [Changes in selected positive health indicators of seniors resulting from Nordic walking]. In: Luczak J, Bronowicki S, eds. Zdrowotne aspekty aktywnosci fizycznej. Poznan: Wielkopolska Wyzsza Szkola Turystyki i Zarzadzania; 2010, 323-329. Polish.

[30] Piech K, Raczynska B. Nordic Walking - Wszechstronna aktywnosc fizyczna [Nordic Walking - A comprehensive physical activity]. Pol J Sport Tourism. 2010;17:69-78. Polish.

[31] Sokeliene V, Cesnaitiene VJ. The influence of Nordic Walking on physical fitness of elderly people. Education Physical Training Sport. Lithuanian Academy of Physical Education. 2011;3(82):45-51. 